\title{
The Most Difficult Vowel Sound Pronunciation among Three Different Semester Students at UIN Sunan Ampel Surabaya: An Acoustic Analysis
}

\author{
Wulansari* \\ Airlangga University \\ Wuland.leo13@gmail.com \\ *corresponding author
}

\author{
Article History \\ Received: 29 February 2020 \\ Reviewed: 10 March 2020 \\ Accepted: 11 April 2020 \\ Published: 30 April 2020

\section{Highlights} \\ - The most difficult vowel or \\ vowel error made by EFL \\ university students are \\ vowel /æ/. \\ - Voice happened, \\ knowledge of \\ pronunciation, phonetic \\ symbols and habituation of \\ speaking English are the \\ causes of students' errors \\ in pronouncing vowel \\ sounds.
}

\begin{abstract}
Speaking language involves different skills like grammar, instruction, vocabulary and pronunciation. in contrast, the researcher only focuses on the students 'errors on six English vowel quality: /II/, /æ/, / $/ \mathrm{N} / \mathrm{/} / \mathrm{o} /$, / $/$, /3:/ made by three different semesters at English Literature, UIN Sunan Ampel Surabaya based on the acoustic analysis. The purposes are to know the result of the formant frequencies, so it appears the percentage of the most difficult vowel. This research used descriptive qualitative method. The result of this research shows that the most difficult vowel or vowel error made by three different semesters are vowel /æa/, the total of incorrect vowel quality is 75 . The average of the students made those errors was about $28.4 \%$. Based on the data it conducted that the common source of student's errors on vowels was because of voice happened, knowledge of pronunciation, phonetic symbols and habituation of speaking English.
\end{abstract}

Keywords: Vowel quality, pronunciation error, acoustic analysis

\section{Introduction}

(Lapoliwa, 1988) stated that language is the tool for people doing communication with others where they can communicate in written or oral language. (Suryatiningsih, 2015) Language is very important to communicate with many people; it makes speakers easy to understand one another. On the other hand, according to (Gilakjani, 2011) Speaking language involves different skills like grammar, instruction, vocabulary and pronunciation. The considerable relation between speaking and pronunciation exist, because every people speak it up with different ways. Their accents can differ in the way in which they pronounce words. Many people get difficulty to learn and to speak English with the correct pronunciation (Hasan, 2014). The problem of the learners who speak English is substitution of sounds. Every human speech sound is either a vowel or a consonant. All words are made up of sequences of vowel sounds and consonant sounds. In addition, many English learners have major difficulties with English pronunciation even after learning the language for years (Gilakjani, 2011).

Some errors occur with the vowel sound. Some vowels are more difficult to identify than others (Barney and Peterson, 1952). In this case, According to (Hasan et all, 2014). Indonesian often gets frustrated when they speak English vowel words, because the vowel sounds are different between Indonesian and English. The first differences are in the number of vowel sounds. Indonesians contains six vowels (Muslich, 2013) while English consist of twelve vowel sounds. The second problem is the pronunciation of three vowel sounds which produce distinct pronunciation between Indonesian and English. For instance, English vowel called /i/, /a/, /e/ 
Wulansari, Tell : Teaching of English Language and Literature Vol. 8, No. 1, 53 - 62 Doi: http://dx.doi.org/10.30651/tell.v8i1.4408

and Indonesian Vowel called /a/, /e/ and /i/. The third reason is duo to the different style of transcription between Indonesian and English.

Indonesian English learners often get some errors of English sounds (Djajaningrat, 2011). (Harmer, 2001) stated the main problem of producing vowel sound in student hearing. Therefore, the important of measuring English vowel sound by using praat software because it can produce data correctly and clearly.

Because of those problems, this research will investigate pronunciation errors of English vowel sounds produced by three different semesters of the student's ability in English Literature at Islamic State University (UIN) of Sunan Ampel Surabaya. (Ladefoged, 1993) said that it is impossible to get good result only using tape recorder because it is hard to know photographs or x-rays showing what speaker do. Therefore, by using Pratt software, the comparison will be made between the native speakers' production of vowel sounds from America and the students'. The finding will help the students to know the quality of their pronunciation and for lecturers; they can examine their student's ability.

\section{Literature Review}

\section{Phonology}

Phonology is the core fields that move forward and basically centered on interaction problem between complementariy approach. In addition, phonology is one of branch in the discipline of linguistics (Odden, 2005). According (Peterson \& Barney, 1952) Phonology has huge relation with the sound of language. (Lapoliwa, 1988) stated that sound of language can be classified in two points of view. First, we can view these sounds as the media of a single language and second, we can also look at these sounds as part of the language system. According (McMahon, n.d. 2006) Phonetic and phonology deal with the ways how human produces and hears speech sound. It is strengthened by (D. Odden, 2005) that both phonetic and phonology learn about the system of speech sound. In addition, (Poole, 1999) argued, phonetic focus on the making of "sound" which is produced in the speech of language. (Lapoliwa, 1988) proposed that phonology which views the sounds of language is commonly called phonetics. While the sounds are the smallest linguistic elements that combine certain patterns (structures) and the same function to distinguish forms from various words. Phonology which views these sounds as part of the language system prevalent in literature is called phonemic.

In the form of vibration frequency, intensity, and timbre, and how the sounds of language can be received by the ear called Phonetic. In addition, Dew and Jensen (1977) said that one of phonetics types is acoustic phonetic. According to Aarts (2006) explained that accoustic phonetics is the physical characteristics of the resulting sound waves that pass between the speaker's vocal tract and the listener's ear, and it is the proccess where by the mechanical movements into the middle and inner ear and perceived at a cortical level as sound.

\section{Vowels Quality}

Ladefoged (1993) stated the transcription of contrasting vowels in English is more difficult that the transcription of consonant because dialects of English differ more in the use of vowel and authorities differ the view of what constitutes an appropriate description of vowels. In other hand, he said that the problem of describing vowels is no distinct boundaries between one type of vowels and another. The articulation place of vowel sound is made by the tongue where 
should not touch any particular place in the mouth, so it is difficult. According to Ladefoged (1993) English vowels are divided into two, those are closed syllables and open syllables. Closed syllables have consonant, in contrast open syllables are vowels at the end. The vowels $[i, \varepsilon, \mathfrak{x}, \Lambda]$ appear in stressed open syllable. Vowel can be divided into a high, mid and low vowel.

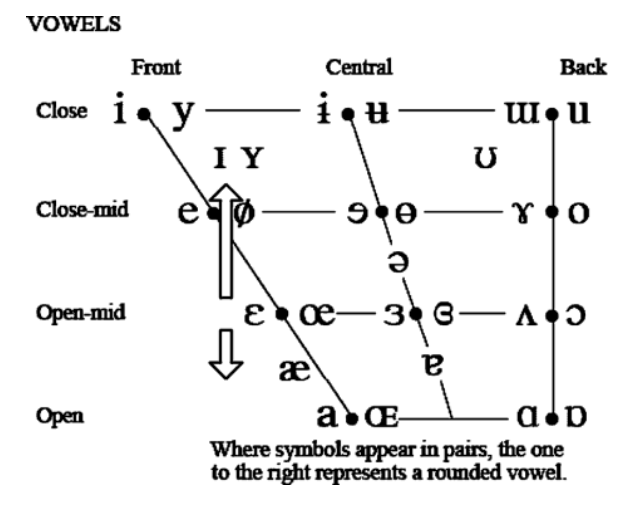

Figure1. A vowel Diagram (Ashby, 2005)

According to (patricia ashby, 2005) stated that vowel quality is the fuction of the combination of the part of the tongue being used. There are two difference of the place of vowel articulation; relative height and low. Three distinctions in each category are called by front, central and back. Vowel can be front or back. In addition, vowels between high and low can be termed mid; vowels between front and back are called central. Vowels find out at the center of a syllable and it is rare to find any sound other than a vowel that will stand alone as a whole syllable (Clark and Yallop, 1995).

\section{Acoustic Analyses}

Acoustic phonetics is a study of science that analyzes physical events or natural phenomena which forms the relationship between the speaker and the listener. Acoustic phonetic studies about the language sound in terms of sound as physical phenomena where it is investigated for the vibrational frequency, amplitude, intensity and timbre (Malmberg, 1963). Besides that there are three characteristics of language sound namely frequency, tempo and loudness. Acoustic phonetic can investigate physical of vowel sound to rate the actual frequencies of the formant which is represent graphically (Johnson, 2011). (Stevens, 1998) stated that the sound produced by the vocal tract can be described in terms of a number of parameters such as relative frequencies of formants, descriptors of the waveform of glottal excitation, amplitude and spectrum of turbulence noise, fundamental frequency changes, etc. These parameters change as the positions and states of the various articulators are manipulated. A decrease in cross-sectional area at the lips (the open end of the tube for a vowel) causes a decrease in the frequency of all formants whilst a decrease in cross-sectional area near the glottis (the closed end of the tube for a voiced sound) causes an increase in the frequency of all formants. There are three ways to hear of knowing sounds; pitch, loudness and quality (Ladefoged, 2005). Pitch and frequency relates each other. When speech sound goes up in frequency, it also goes up in pitch. The frequency (pitch) and overall intensity (loudness) are calibrated with scales in Hz. Sound waves rapidly occur in the speaker's vocal organs that consist of air pressure. The characteristics of overtones called formants of the 
vowels. The formants that characterize different vowels are the result of the different ways in which the air in the vocal tract vibrates.

Johnson (2011) introduced, this kind of acoustic analysis can be analyzed by using computer program or software to know their components of sound. In addition the display is called a spectrogram. The website that can be used to know spectrograms is namely Praat Software. It shows

\section{Pronunciation Error}

There are two aspects of pronunciation which are speech and language. Pronunciation also produces sound to create meaning, such as intonation, phrasing, stress and rhythm. The English alphabets in Indonesia and English have the same quantity but pronounced by different way. In this case, English is well known as a foreign language where Indonesian people do not use in daily speaking. On other hand, learners who try to speak English will figure out that learning process is not easy because there are several English aspects that need to be comprehended. Brown (1994) some factors affect pronunciation, those are native language, age, exposure, innate phonetic ability, identify and language ego.

\section{Methodology}

\section{Research design, subject and the instrument}

This research used descriptive qualitative method and concerned with the acoustics phonetic on the vowel quality sound and showed the most difficult vowel produced by three different semesters in English Literature at State Islamic University (UIN) of Sunan Ampel Surabaya. Three different semesters are chosen because the researcher wanted to know the different result showed. Handbook of UIN Sunan Ampel Surabaya (2013) showed that the English student will get the pronunciation class in the second semester. Therefore, the researcher wanted to compare the second, fourth, and sixth semester. Whether the students of second semester have good result due to the pronunciation lesson, the students of fourth semester had already gotten for one year and the students of sixth semester had already gotten for two years after the lesson.

The subject of this research was the English Students that consist of 20 students of each semester, so total of them are 60 students. Those were in the second, fourth and sixth semester of English Literature at Islamic State University of Sunan Ampel Surabaya and 15 people that came from America. The researcher met American in some activities when they were in Surabaya. They came to Surabaya duo to learn of Muslim religion and holiday. Then, the researcher asked them to help about this research and to pronounce vowel sounds showed in the table1. Then, the researcher got the data from each semester after coming to every class of the semester and asked them to mention the words that have already been chosen by the researcher, and then the researcher recorded their voice.

There are two instruments of this study. The first, the researcher itself did through recording, collecting the data, identifying, comparing and counting. The data got from elicitation. The second was praat software. It is computer software that is used for analyzing physical properties of the phonetics. It is used as a tool to identify the formant frequency of data sources in this research. Praat software describes speech acoustic signals.

The first method done by the researcher is to analyze the result of vowel quality from America. After getting the data from the Americans, the researcher compared with the data 
Wulansari, Tell : Teaching of English Language and Literature Vol. 8, No. 1, 53 - 62 Doi: http://dx.doi.org/10.30651/tell.v8i1.4408

from the English students. It was chosen because the researcher wanted to know the most difficult vowel and measured the vowel quality of /I/, /æ/, / / /, / :/, / / /, /3:/ of university student. Then the researcher compared all the data. The students will get low vowel score if their score is lower than American. Middle and high vowels will appear if their scores are as nearly as to the results of Americans. The researcher measured with this form above to measure the result.

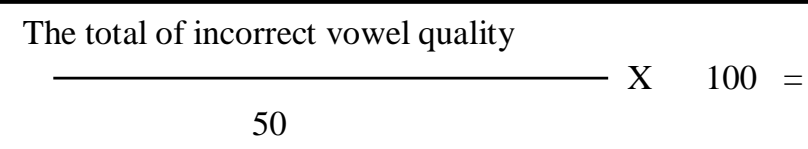

\section{Findings and Discussion}

\section{Findings}

The description of vowel sound, those are vowels, pitch, and overtone. The vowel sounds may be said on a variety of notes (voice pitches), but they are distinguished from one another by two characteristic vocal tract pitches associated with their overtones. The other is low for vowels in which the tongue position is high and high for vowels in which the tongue position is low. It corresponds (inversely) to what we called vowel height in articulatory terms. These characteristic overtones are called the formants of the vowels, the one with the lower pitch (distinguishable in creaky voice) being called the first formant and the higher one (the one heard when whispering) the second formant ( Ladefoged \& Johnson, 2011).

This study showed error analysis to describe errors among the three different semester of the student by measuring the result of American pronunciation using Praat software. To know the students' ability in pronunciation, the researcher gave 30 words to the students and Americans, and then calculated the students' errors. Here are the words and the phonetic transcription;

Table 1. The words and the phonetic transcription 
Wulansari, Tell : Teaching of English Language and Literature Vol. 8, No. 1, 53 - 62 Doi: http://dx.doi.org/10.30651/tell.v8i1.4408

\begin{tabular}{|c|c|c|c|c|c|}
\hline$/ \mathbf{I} /$ & $\begin{array}{l}\text { BIT / } \\
\text { SIT } \\
\text { QUIZ } \\
\text { LICK } \\
\text { TICK }\end{array}$ & $\begin{array}{l}\text { /Bit/ } \\
\text { /Sit/ } \\
\text { /Kwiz/ } \\
\text { /Lik/ } \\
\text { /Tik/ }\end{array}$ & $/ \mathbf{b}: /$ & $\begin{array}{l}\text { CALL } \\
\text { GAIL } \\
\text { BOARD } \\
\text { SAW } \\
\text { FALL }\end{array}$ & $\begin{array}{l}\text { /Ko:1/ } \\
\text { /Go:1/ } \\
\text { /Bo:d/ } \\
\text { /So:/ } \\
\text { /Fo:1/ }\end{array}$ \\
\hline$/ \mathfrak{a} /$ & $\begin{array}{l}\text { HAT } \\
\text { GAD } \\
\text { GAG } \\
\text { CAB } \\
\text { CAT }\end{array}$ & $\begin{array}{l}\text { /Hæt/ } \\
\text { / Gæg/ } \\
\text { / Kæg/ } \\
\text { /Kæt/ } \\
\text { /Kæt }\end{array}$ & $|\sigma|$ & $\begin{array}{l}\text { WOOD } \\
\text { PUT } \\
\text { OUT } \\
\text { LUCK } \\
\text { COULD }\end{array}$ & $\begin{array}{l}\text { /Wud/ } \\
\text { /Put/ } \\
\text { /Avt/ } \\
\text { /Luk/ } \\
\text { /'Kod/ }\end{array}$ \\
\hline$/ \mathbf{L} /$ & $\begin{array}{l}\text { MUD } \\
\text { CUP } \\
\text { TUSK } \\
\text { TUSSLE } \\
\text { TUNNEL }\end{array}$ & $\begin{array}{l}\text { /M } \Lambda \mathrm{d} / \\
/ \mathrm{K} \wedge \mathrm{p} / \\
/ \mathrm{T} \Lambda \mathrm{sk} / \\
/ ' \mathrm{~T} \Lambda \mathrm{si} / \\
\text { /'T } \Lambda \mathrm{nl} /\end{array}$ & /3:/ & $\begin{array}{l}\text { WORD } \\
\text { FUR } \\
\text { QUIRK } \\
\text { TURN } \\
\text { LEARN }\end{array}$ & $\begin{array}{l}\text { /W3:d/ } \\
\text { /F3:(r)/ } \\
\text { /Kw3:k/ } \\
/ \mathrm{T}_{3}: \mathrm{n} / \\
\text { /L3:n/ }\end{array}$ \\
\hline
\end{tabular}

Table 1 showed the American English. They pronounced the words above and the researcher recorded.

Table 2. The Average of vowel quality of Native American

\begin{tabular}{cc}
\hline Vowel & Result \\
\hline$/ \mathbf{I} /$ & $>400 \mathrm{~Hz}$ \\
\hline$/ \mathfrak{a} /$ & $>600 \mathrm{~Hz}$ \\
\hline$/ \mathbf{\Lambda} /$ & $>550 \mathrm{~Hz}$ \\
\hline$/ \mathbf{5 : /}$ & $>450 \mathrm{~Hz}$ \\
\hline$/ \boldsymbol{\sigma} /$ & $>450 \mathrm{~Hz}$ \\
\hline$/ \mathbf{3 : /}$ & $>450 \mathrm{~Hz}$ \\
\hline
\end{tabular}


Table 3. The Value Data of Second Semester

\begin{tabular}{|c|c|c|}
\hline VOWEL & $\begin{array}{c}\text { The total of Incorrect } \\
\text { vowel quality }\end{array}$ & $\begin{array}{l}\text { The percentage of } \\
\text { incorrect vowel quality }\end{array}$ \\
\hline$/ \mathbf{I} /$ & 7 & $14 \%$ \\
\hline$/ \mathfrak{a} /$ & 34 & $68 \%$ \\
\hline$/ \mathbf{N} /$ & 29 & $58 \%$ \\
\hline /o:/ & 22 & $44 \%$ \\
\hline$/ \delta /$ & 12 & $24 \%$ \\
\hline /3:/ & 16 & $32 \%$ \\
\hline total & 120 & \\
\hline
\end{tabular}

Table 3 showed that there were 120 vowel errors made by second semester. The problem is when the students study pronunciation course in the second semester. So it means they are still in the process on leaning pronunciation.

Table 4. The Frequency Data of Fourth Semester

\begin{tabular}{ccc}
\hline VOWEL & $\begin{array}{c}\text { The total of Incorrect } \\
\text { vowel quality }\end{array}$ & $\begin{array}{c}\text { The percentage of incorrect } \\
\text { vowel quality }\end{array}$ \\
\hline /I/ & 2 & $4 \%$ \\
\hline /a/ & 17 & $34 \%$ \\
\hline$/ \mathbf{A} /$ & 9 & $18 \%$ \\
\hline /o:/ & 2 & $4 \%$ \\
\hline /\%/ & 4 & $8 \%$ \\
\hline /3:/ & 7 & $14 \%$ \\
\hline total & 41 & \\
\hline
\end{tabular}

Table 4 showed that there were 41 vowel errors made by fourth semester. The data showed that decreasing number from second to fourth semester. It occurred due to fourth semester having knowledge of pronunciation. On other hand, second semester had gotten the lesson for one year. 
Table 5. The Frequency Data of Sixth Semester

\begin{tabular}{ccc}
\hline VOWEL & $\begin{array}{c}\text { The total of Incorrect } \\
\text { vowel quality }\end{array}$ & $\begin{array}{c}\text { The percentage of incorrect } \\
\text { vowel quality }\end{array}$ \\
\hline /I/ & 17 & $34 \%$ \\
\hline /æ/ & 24 & $48 \%$ \\
\hline / $/$ & 16 & $32 \%$ \\
\hline /5:/ & 12 & $24 \%$ \\
\hline /\%/ & 15 & $30 \%$ \\
\hline /3:/ & 19 & $38 \%$ \\
\hline total & 103 & \\
\hline
\end{tabular}

Table 5 showed that there were 103 vowel errors made by sixth semester. The data showed that increasing number from fourth to sixth semester. It occurred because sixth semester had the pronunciation lesson for two years. It means that they forgot how to pronounce the correct pronunciation.

\section{Discussion}

It is demonstrated from the data above taken from American and three different semesters. Here the result of the total data which showed the most difficult vowel of the English Literature students at UIN Sunan Ampel Surabaya.

Table 6. The Data Frequency of Three Semesters

\begin{tabular}{|c|c|c|}
\hline VOWEL & $\begin{array}{c}\text { The total of Incorrect } \\
\text { vowel quality }\end{array}$ & $\begin{array}{l}\text { The percentage of } \\
\text { incorrect vowel quality }\end{array}$ \\
\hline$/ \mathbf{I} /$ & 26 & $9.8 \%$ \\
\hline$/ \mathfrak{a} /$ & 75 & $28.4 \%$ \\
\hline$/ \mathrm{N} /$ & 54 & $20.4 \%$ \\
\hline /):/ & 38 & $14.4 \%$ \\
\hline$/ \delta /$ & 29 & $11 \%$ \\
\hline /3:/ & 42 & $16 \%$ \\
\hline Total & 264 & $100 \%$ \\
\hline
\end{tabular}

From the data above we can see that there are 264 students made vowel errors. The researcher can get the percentage of incorrect vowel quality from courting by using this formula; 


\section{The total of incorrect vowel quality}

\section{4}

Table6 shows that there are 264 data of vowel errors. From the table above, the researcher can see which students got difficulties in pronouncing vowel $/ \mathbf{I} /$, the total of incorrect vowel quality is 26 , and the percentage of the error population is $9.8 \%$. The students got difficult in pronouncing vowel $/ \mathfrak{x} /$, the total of incorrect vowel quality is 75 , and the percentage of the error population is $28.4 \%$. The students had the difficulties in pronouncing vowel $/ \mathbf{N} /$, the total of incorrect vowel quality is 54 , and the percentage of the error population is $20.4 \%$. The data in pronouncing vowel / $\mathbf{s}:$, the total of incorrect vowel quality is 38 , and the percentage of the error population is $14.4 \%$. The data in pronouncing vowel $/ \mho /$, the total of incorrect vowel quality is 29 , and the percentage of the population error is $11 \%$. The students got the difficulties in pronouncing vowel /3:/, the total of incorrect vowel quality is 42 , and the percentage of the error population is $16 \%$.

The researcher found that the most difficult vowel or vowel error made by three different semesters are vowel /æ/, we can see that the total of incorrect vowel quality is 75 , and the percentage of the error population is $28.4 \%$. The type of vowel is low because the tongue position, pitch and loudness occurred in the wrong position.

The error of making by students can be caused by some factors. The first factor is the errors are generally influenced because of voice (low and height the voice), short length of pronunciation, seriousness factor, and the important thing is about knowledge of phonetic (long and short vowel). Second, the situation occurred when the researcher recorded their voice. Third factors, they did not understand or confused how to pronounce /a/ sounds. The last factors happened because they did not use to it in every daily, even the have to speak English in the class but they did not use it in their conversation. This error can be influenced by some factors.

\section{Conclusion}

The researcher concludes that the three different semesters of English Literature students UIN Sunan Ampel Surabaya produced many errors in their English pronunciation on vowels sounds. It was known most of the students produce pronunciation error on [æ] vowel. It was proved for about 75 of incorrect vowel quality and the percentage of the population that made this error is $28.4 \%$. The words are "hat", "gad", "gag", "cab", and "cat". 
Wulansari, Tell : Teaching of English Language and Literature Vol. 8, No. 1, 53 - 62 Doi: http://dx.doi.org/10.30651/tell.v8i1.4408

\section{References}

Barney, H. L. and peterson. (1952). Control Metod used in a Study of the Vowel. The Acoustical Society of America, 2, 175-184.

Dew, D., \& Jensen, P. J. (1977). Phonetics Processing: The Dynamics of Speech. Colombus. $\mathrm{OH}$ : Merril.

D. Odden. (2005). An Introducing phonology. Cambridge: Cambridge University Pres.

Djajaningrat, L. (n.d.). The Mapping of Pronunciation Error. Jakarta: Universitas Darma Persada.

Gilakjani, P. . (2011). A Study on the Situation of Pronunciation Instruction in ESL/EFL Classroom. English Language Teaching, 4(3).

Hasan, E. M. I. (2014). Pronunciation Problems: A Case Study of English Language Students at Sudan University of Science and Technology. Canadian Center of Science and Education, 4. Retrieved from http://dx.doi.org/10.5539/ells.v4n4p31

J. Harmer. (2001). The Practical of English Languge Teaching. England: Pearson education limited.

Ladefoged, P. (1993) A Course in Phonetics. (3rd Edition) New York: Harcourt Brace Jovanovich.

Lapoliwa, H. (1988). Pengantar Phonology I: Fonetik (1st ed.). Jakarta: Departement Pendidikan dan Kebudayaan.

Malmberg, B. (1963). Phonetic Acoustic. New York: Dover Publication.

McMahon, B. A. and. (n.d.). English Linguistics. United Kingdom: Blackwell Publishing Ltd.

Muslich, M. (2013). Fonologi Bahasa Indonesia Tinjauan Desriptif System Bunyi Bahasa Indonesia (5th ed.; Bumi Aksara, ed.). Jakarta.

Ashby. Patricia. (2005). Speech sound (2nd ed.; Routledge, ed.). Canada and USA: British Library cataloguing.

Peterson, G. E., \& Barney, H. L. (1952). Control Methods Used in a Study of the Vowels. Journal of the Acoustical Society of America. https://doi.org/10.1121/1.1906875

Poole, S. C. (1999). An Introduction to Linguistic. United Kingdom: Macmillan Publishers Ltd. Suryatiningsih, N. (2015). A Study On The Students' Ability In Pronouncing Diphthongs At Stkip Pgri Pasuruan. Jurnal Dimensi Pendidikan Dan Pembelajaran Vol. 3 No. 2, 3(2). Stevens, K.N. (1998). Acoustic Phonetics. The MIT Press, Cambridge Massachusetts, USA. 